\title{
Duddingtonia flagrans preying a plant parasitic nematode ${ }^{1}$
}

\author{
T. S. A. Monteiro ${ }^{a *}$ (D) H. M. Balbino (D), I. N. K. de Mello ${ }^{b}$ (D), R. R. Coutinho ${ }^{a}$ (D), \\ J. V. de Araújo ${ }^{b}$ (D) and L. G. Freitas ${ }^{a}$ (D)
}
${ }^{a}$ Departamento de Fitopatologia, Universidade Federal de Viçosa - UFV, Av. Peter Henry Rolfs, s/n, Campus Universitário, CEP 36570-900, Viçosa, MG, Brasil
${ }^{\text {b}}$ Departamento de Veterinária, Universidade Federal de Viçosa - UFV, Av. Peter Henry Rolfs, s/n, Campus Universitário, CEP 36570-900, Viçosa, MG, Brasil
*e-mail: thalita.monteiro@ufv.br

Received: 30 July 2018 - Accepted: 1 October 2018 - Distributed: February 28, 2020

(With 2 figures)

${ }^{1}$ Part of the thesis of the first and second author, for a postgraduate degree in Plant Pathology,

Universidade Federal de Viçosa.

\begin{abstract}
The root-knot nematodes (Meloidogyne spp. Goeldi) are among the plant parasitic nematodes that cause the greatest losses in agriculture. In order to reduce the damage caused by these pathogens, biological control has become popular because it can be used with other control methods, does not leave residues in food and, in most cases, does not cause an impact on the environment.
\end{abstract}

Duddingtonia flagrans has been studied in the control of parasitic nematodes of animals. This biological control agent is a soilborne fungus that promotes the growth of plants, produces chlamydospores and its nematophagous activity is guaranteed by adhesive hyphae and three-dimensional adhesive networks that capture the nematodes (Larsen, 2000; Monteiro et al., 2018). Duddingtonia flagrans also produces important proteases during the interaction with the nematode cuticle, as observed in parasitic trichostrongylides larvae of domestic animals (Cruz et al., 2015). The ability of this antagonist to prey on plant parasitic nematode was observed by Pandit et al. (2017), in vitro, with Meloidogyne spp., but information on the reduction of these nematodes populations in soil by the fungus has not been provided. The purpose of this work was to study the ability of $D$. flagrans to prey on Meloidogyne javanica in microcosm soil and to capture images of the live action of the fungus on the nematode.

The nematode inoculum was composed of eggs of M. javanica, collected from tomato roots maintained in a greenhouse. The mass production of chlamydospores of D. flagrans was performed in crushed corn. D. flagrans (AC001) fungal isolate belongs to the collection of the Parasitology Laboratory of the Department of Veterinary at the Universidade Federal de Viçosa.

Predation in microcosm soil: in this experiment, the predatory capacity of fungus $D$. flagrans, tested at different concentrations, on M. javanica was performed in vitro. $200 \mathrm{~mL}$ polypropylene pots were filled with $50 \mathrm{~g}$ of sterile soil (microcosms) infested with 1,500 eggs of nematode. Each pot received 0, 2,500, 5,000, 10,000, $15,000,20,000$ or 25,000 chlamydospores of $D$. flagrans per gram of soil and the pots were then incubated for 15 days at $26^{\circ} \mathrm{C}$. After this time juveniles were collected from the soil using the Baermann funnel technique. The volume was transferred to a Peters counting chamber and the number of juveniles were quantified by counting under a light microscope. The treatments were replicated four times and arranged in a completely randomized design.

The capturing images of the interaction between fungus and nematode were taken in petri dishes with $2 \%$ of Water-Agar (WA) containing streptomycin. Each petri dish received, on the same day, D. flagrans and an average of 37 juveniles of M. javanica, previously disinfested with ampicillin and chloramphenicol suspension, at concentrations of 200 and $300 \mathrm{ppm}$, respectively. The control of the treatment was performed in petri dishes containing only the fungus. The petri dishes were stored at $28^{\circ} \mathrm{C}$ for 48 hours. The culture medium with $D$. flagrans and nematodes was sectioned and observed using an stereoscopic microscope with image capture. The data from "Predation in microcosm soil" was evaluated by means of regression, at $1 \%$ of probability.

The increase in doses of $D$. flagrans reduced the number of second stage juveniles up to the predicted concentration of 8,201 chlamydospores $\mathrm{g}^{-1}$ of soil (estimated value using the regression model), meaning a $72.7 \%$ reduction of $M$. javanica (Figure 1). The reduction of the number of juveniles with the application of $D$. flagrans can be explained by the ability of this fungus to form traps in response to the presence and migration of nematodes or substances secreted by them.

After 48 hours of $D$. flagrans fungus being in contact with $M$. javanica juveniles, in WA, the fungus produced adhesive nets that captured root-knot nematode juveniles (Figure 2). In addition, it was possible to observe a large production of chlamydospores, when compared with the absence of the nematode (data was not quantified).

When placed in the presence of Meloidogyne spp. for $24 \mathrm{~h}$, the fungus D. flagrans had increased the protease activity (Pandit et al., 2014). These enzymes may have an effect on nematodes and are related to the predation of $M$. javanica, and consequently, the reduction of this nematode in the microcosm soil, as seen in this work. However, it should be highlighted that more studies are 


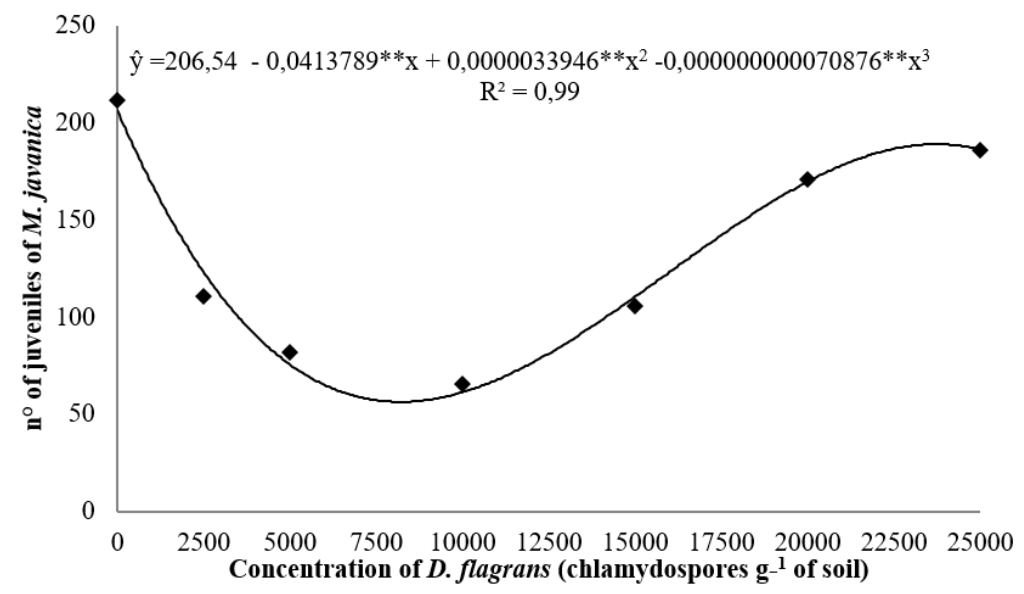

Figure 1. Number of juveniles of Meloidogyne javanica 15 days after application of different concentrations of chlamydospores of Duddingtonia flagrans in soil infested with 1,500 eggs. **significant at 1\% by the F test.
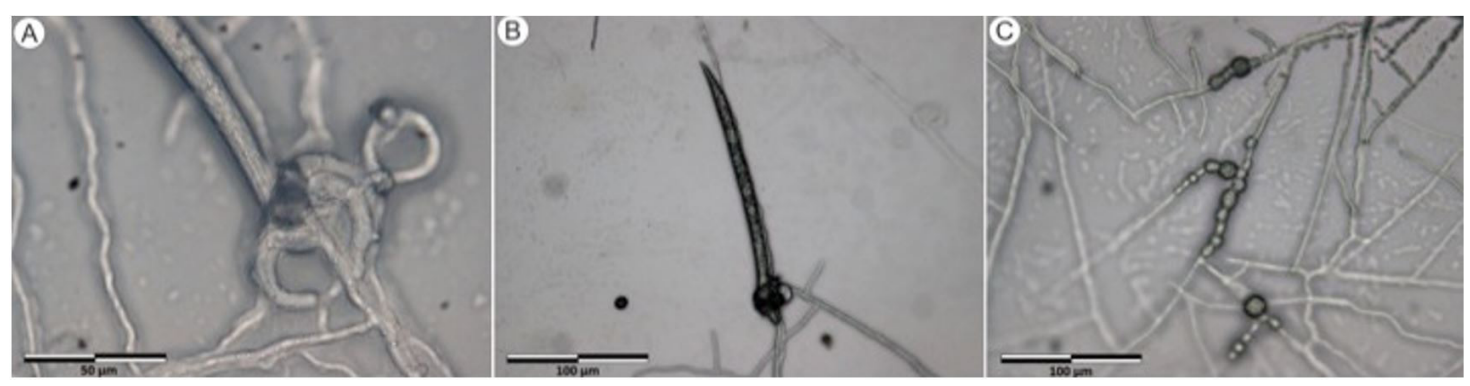

Figure 2. Images from the interaction between Duddingtonia flagrans and Meloidogyne javanica; (A) Adhesive nets formed by D. flagrans to capture root-knot nematode; (B) M. javanica second-stage juvenile captured by D. flagrans: (C) chlamydospores of the fungus D. flagrans.

needed to better understand the interactions between D. flagrans and plant parasitic nematodes.

The fungus $D$. flagrans produces nets that capture $M$. javanica and, consequently, predates the nematode reducing its viability in soil.

\section{Acknowledgements}

Funding from the Conselho Nacional do Desenvolvimento Científico e Tecnológico (CNPq), Coordenação de Aperfeiçoamento de Pessoal de Nível Superior (CAPES) and Fundação de Amparo à Pesquisa do Estado de Minas Gerais (FAPEMIG) are acknowledged.

\section{References}

CRUZ, D., COSTA, L., ROCHA, L., RETAMAL, C., VIEIRA, R., SEABRA, S., SILVA, C., DAMATTA, R. and SANTOS, C., 2015. Serine proteases activity is important for the interaction of nematophagous fungus Duddingtonia flagrans with infective larvae of trichostrongylides and free-living nematodes Panagrellus spp. Fungal Biology, vol. 119, no. 8, pp. 672-678. http://dx.doi. org/10.1016/j.funbio.2015.03.005. PMid:26228558.

LARSEN, M., 2000. Prospects for controlling animal parasitic nematodes by predacious micro fungi. Parasitology, vol. 120, no. 7, suppl., pp. 121-131. http://dx.doi.org/10.1017/S0031182099005739. PMid: 10874715.

MONTEIRO, T.S.A., VALADARES, S.V., MELLO, I.N.K., MOREIRA, B.C., KASUYA, M.C.M., ARAÚJO, J.V. and FREITAS, L.G., 2018. Nematophagus fungi increasing phosphorus uptake and promoting plant growth. Biological Control, vol. 123, pp. 71-75. http://dx.doi.org/10.1016/j.biocontrol.2018.05.003.

PANDIT, R.J., BHATT, V.D., MUKHOPADHYAYA, P.N., JOSHI, C.G. and KUNJADIA, A.P., 2014. Biochemical and molecular characterization of protease from Arthrobotrys conoides and Duddingtonia flagrans. International Journal of Advanced Biotechnology Research, vol. 5, pp. 552-561.

PANDIT, R., PATEL, R., PATEL, N., BHATT, V., JOSHI, C., SINGH, P.K. and KUNJADIA, A., 2017. RNA-Seq reveals the molecular mechanism of trapping and killing of root-knot nematodes by nematode-trapping fungi. World Journal of Microbiology \& Biotechnology, vol. 33, no. 4, pp. 1-19. http://dx.doi.org/10.1007/ s11274-017-2232-7. PMid:28260194. 